\title{
A1 Hydronephrosis
}

National Cancer Institute

\section{Source}

National Cancer Institute. A1 Hydronephrosis. NCI Thesaurus. Code C123164.

Antenatal hydronephrosis with the following clinical findings: 1) an anterior-posterior renal pelvis diameter (APRPD) of 4 to less than $7 \mathrm{~mm}$ at less than 28 weeks, 2) to less than10 $\mathrm{mm}$ at greater than or equal to 28 weeks, and 3) may have central calyceal dilation.

(Adapted from: Hiep T. Nguyen, Carol B. Benson, Bryann Bromley, Jeffrey B. Campbell, Jeanne Chow, Beverly Coleman, Christopher Cooper, Jude Crino, Kassa Darge, C.D.

Anthony Herndon, Anthony O. Odibo, Michael J.G. Somers, Deborah R. Stein;

Multidisciplinary consensus on the classification of prenatal and postnatal urinary tract

dilation (UT D classification system); Pediatric Urology; December 2014 Volume 10, Issue

6, Pages 982-998) 